\title{
Metastasis-Associated Protein MTA2
}

National Cancer Institute

\section{Source}

National Cancer Institute. Metastasis-Associated Protein MTA2. NCI Thesaurus. Code C92690.

Metastasis-associated protein MTA2 (668 aa, $75 \mathrm{kDa}$ ) is encoded by the human MTA2 gene. This protein plays a role in chromatin modification. 